\title{
DAR ROZUMU I JEGO DAWCA W ŻYCIU CHRZEŚCIJANINA**
}

„W odnowionej, choć przecież odwiecznej perspektywie wszyscy chrześcijanie są powołani do tego, by być świętymi, to znaczy ludźmi, którzy naprawdę całym sercem pragna, aby wszystko, co czynią, było spełniane według woli Bożej. Wydaje się to takie proste, a w rzeczywistości okazuje się trudne i najczęściej jest całkowicie zaniechane. Nowy nurt w tej sferze jest jednym z najbardziej widocznych znamion działania Ducha Świętego w naszej epoce"1.

\section{WPROWADZENIE}

Dwa tysiące lat temu Chrystus powierzył nam zadanie budowania królestwa Bożego na ziemi, głoszenia Dobrej Nowiny o Nim aż po krańce świata. Rozsyłając apostołów, aby szli i nauczali, Chrystus powiedział: „Nie bierzcie nic na drogę: ani laski, ani torby podróżnej, ani chleba, ani pieniędzy, nie miejcie

* Ks. Zdzisław Pawlak - dr hab. nauk humanistycznych w zakresie filozofii, profesor Uniwersytetu M. Kopernika w Toruniu (Zakład Filozofii Chrześcijańskiej na Wydziale Teologicznym), także w Studium Teologii we Włocławku (filia Papieskiego Wydziału Teologicznego w Warszawie), członek redakcji „Studiów Włocławskich”.

** Jest to poszerzona wersja wykładu wygłoszonego 5 grudnia 2007 r. na Wydziale Teologicznym UMK w Toruniu w ramach tzw. wykładów otwartych pt. „Ty darzysz łaską siedemkroć" - dary Ducha Świętego odczytane dzisiaj.

${ }^{1}$ S. Swieżawski, Alfabet duchowy, Kraków 2004, s. 70. 
też dwóch sukien" (Łk 9, 3). Jezus już wtedy przypomniał więc swoim uczniom, aby nie pokładali nadziei w mocy tylko ludzkiej, w swoich tylko talentach, nawet gdyby posiadali ich wiele, bo człowiek nie jest w stanie sam, własną mocą budować królestwa Bożego, jeśli Duch Świętego nie wesprze. Tak jak apostołowie, do swojej misji również i my potrzebujemy przeogromnej mocy, ale innej, większej niż tamte tylko ludzkie środki. Jest to moc Ducha Świętego, której potrzebuje każdy człowiek w swoim życiu i spełnianiu zadania, które Bóg mu powierza. „Ważnym celem będzie zatem ponowne odkrycie Ducha jako Tego, który w ciągu dziejów buduje królestwo Boże i przygotowuje jego ostateczne objawienie w Jezusie Chrystusie, działając ożywczo we wnętrzu człowieka i sprawiając, że w codziennym ludzkim doświadczeniu kiełkują już ziarna ostatecznego zbawienia, które nastąpi na końcu czasów"2.

My, chrześcijanie, usiłując pełnić swoją misję i żyć tak, jak Chrystus pragnie, czynimy to jednak niekiedy, nie korzystając z pomocy Ducha Świętego. Mówiąc językiem obrazowym, jesteśmy niejako „niepodłączeni” do źródła, czyli mocy Ducha Świętego, którą nam Jezus obiecałª . Dlatego z pewnością nieprzypadkowo Jan Paweł II w encyklice o Duchu Świętym (Dominum et Vivificantem) aż 65 razy używa terminu "moc”, mówiąc o Jego działaniu. Chce nam w ten sposób uświadomić, że Kościół współczesny cierpi nie z powodu niedoboru mocy Bożej, spadku napięcia Bożej energii, ale przede wszystkim dlatego, że jesteśmy z własnej winy „niepodłączeni” do źródła mocy, którą daje Duch Święty. Chce nas przekonać, że musimy w swoim życiu korzystać z tej mocy Ducha Świętego, którą jest On sam i Jego dary.

W niniejszym opracowaniu zwrócimy najpierw ogólnie uwagę na rzeczywistość Ducha Świętego i Jego darów we wspólnocie Kościoła. Następnie zaś, aby lepiej zrozumieć istotę i działanie darów Ducha Świętego w życiu chrześcijanina, przyjrzymy się bliżej jednemu z nich, a mianowicie darowi rozumu.

\section{DUCH ŚWIĘTY I JEGO DARY WE WSPÓLNOCIE KOŚCIOŁA}

W zakończeniu encykliki Dominum et Vivificantem Jan Paweł II napisał:

Kościół nieustannie wyznaje: „jest w naszym stworzonym świecie Duch, który jest Darem niestworzonym". Jest to Duch Ojca i Syna: tak jak Ojciec i Syn jest On nie stworzony, nieskończony, przedwieczny, wszechmocny, Bóg i Pan. Ten Boży Duch „napełnia okrąg ziemi” - i wszystko, co stworzone, w Nim rozpoznaje źródło swej tożsamości, w Nim znajduje swój właściwy, transcendentny wyraz. Wszystko też, „co stworzone, ku Niemu się zwraca” i na Niego „oczekuje”. Jego przyzywa samą swoją istotą. Do Niego, jako

${ }^{2}$ Jan Paweł II, Tertio millennio adveniente, $\mathrm{nr} 45$.

${ }^{3}$ Por. T. Forrest, Nie wysytaj Boga na urlop, "Szum z nieba” 2 (2007), s. 4-5.

${ }^{4}$ Zob. Jan Paweł II, Dominum et Vivicantem, nr 25. 
do Parakleta, do Ducha Prawdy i Miłości, zwraca się „człowiek, który żyje Prawdą i Miłością" i który bez tego źródła Prawdy i Miłości „żyć nie może”. Do Niego zwraca się Kościół, będący w sercu ludzkości, przyzywając dla wszystkich i wszystkich obdarzając darami tej „Miłości”, która „rozlana jest w sercach naszych" ${ }^{\prime \prime}$.

Przez dość długi okres czasu w historii Kościoła niewiele się mówiło o Duchu Świętym. Może dlatego, że Jego obecność pośród nas jest tak tajemnicza, że nie próbowano nawet zgłębiać jej tajników. Oczywiście nikt nie negował Jego działania w kształtowaniu dojrzałości duchowej chrześcijanina, zwłaszcza w sakramencie bierzmowania, ale nie było to jeszcze ukazaniem właściwej roli, jaką pełni On w Kościele i życiu jego członków. Tak trudno bowiem wyobrazić sobie Jego obecność pośród nas, siłę Jego duchowego oddziaływania.

Zatrzymajmy się więc przez chwilę w naszej refleksji przy tym, jak powiedział jeden z prawosławnych teologów, „zapomnianym Bogu” - Duchu Świętym i Jego darach 6 . Hans Urs von Balthasar nazywa Go „Nieznany poza Słowem" (der Unbekannte jenseits der Wortes). Do tego określenia nawiązuje Yves Congar w swojej trylogii o Duchu Świętym".

Pismo Święte niewiele mówi o Duchu Świętym, i to jeszcze w sposób bardzo tajemniczy. I tak z Biblii wiemy, że Duch ukazał się nad Jordanem w postaci gołębicy, gdy Jezus wchodził w nurt rzeki. Wiemy również, że Duch Święty w postaci ognistych płomieni w dniu Pięćdziesiątnicy zstąpił na apostołów, napełniając ich swoją mocą. A moc Ducha Świętego ujawnia się i działa w niektórych momentach i aspektach życia jerozolimskiej wspólnoty, o której w sposób szczególny mówią Dzieje Apostolskie. Całe życie pierwszej jerozolimskiej gminy nosi na sobie działanie Ducha Świętego będącego jej niewidzialnym

${ }^{5}$ Tamże, nr 67. Gdy chodzi o problematykę Ducha Świętego i Jego działanie w Kościele, to oprócz lektury encykliki o Duchu Świętym Dominum et Vivificantem można polecić z olbrzymiej literatury na ten temat (zob. S. Gręś, Polska bibliografia pneumatologiczna 1946-1998, Włocławek 2000) zwłaszcza trzytomowe dzieło Y. Congara Wierze w Ducha Świętego, Warszawa 1995 (jest to interpretacja teologiczna w ramach teologii Ducha Świętego i Jego roli w Kościele. Congar zajmuje się tutaj aspektami teoretycznymi, obiektywnymi przesłankami całego procesu poznawania Ducha Świętego i Jego działania). Warto również sięgnąć do następujących publikacji: B. Stubenrauch, Pneumatologia - traktat o Duchu Świętym, Kraków 1999 (opracowanie podręcznikowe); Z. Radziwołek, Dary Ducha Świętego w życiu chrześcijanina. Studium biblijne na podstawie "Corpus Paulinum", Legnica 2006; A. Drago, Dary Ducha Świętego, Kraków 1998. Również cały zeszyt „Ateneum Kapłańskiego” (z. 540 z 1999 r.) zatytułowany W mocy Ducha Świętego jest poświęcony darom Ducha Świętego. Niestety, nie ma tutaj (podobnie jak w większości opracowań) wyodrębnionego daru rozumu. W sposób popularny tę problematykę, zwłaszcza działania Ducha Świętego, ukazują „Zeszyty Odnowy w Duchu Świętym" oraz dwumiesięcznik Katolickiej Odnowy Charyzmatycznej.

${ }^{6}$ Zob. W. Kawecki, Bóg pochylony nad człowiekiem, Kraków 2000, s. 141-142.

${ }^{7}$ Zob. Y. Congar, Wierzę w Ducha Świętego, t. 2, Warszawa 1995, s. 48-51. 
przewodnikiem i ożywicielem. Można za Janem Pawłem powiedzieć, że Duch Święty jest obecny w Kościele i działa w nim od samych jego początków, „w sercu judaizmu". To Duch Święty poprowadził apostołów i ich współpracowników, aby dar Pięćdziesiątnicy zanieśli do wszystkich narodów ${ }^{8}$.

Niezwykłym doświadczeniem działania Ducha Świętego w naszych czasach był niewątpliwie Sobór Watykański II. Jego dokumenty wielokrotnie i wprost wskazują na ożywiającą i uświęcającą obecność Ducha Świętego we współczesnym Kościele9.

Zesłanie Ducha Świętego, które dało początek Kościołowi i w którym otrzymał on wszystkie dary potrzebne dla wypełnienia misji zbawienia, nie należy tylko do przeszłości. Będąc faktem historycznym, pozostaje równocześnie wciąż aktualnym doświadczeniem. Bez ożywiającego tchnienia Bożego Ducha Kościół nie mógłby nie tylko objawić się światu w dzień Pięćdziesiątnicy, lecz nie mógłby istnieć również dziśn ${ }^{10}$.

Katechizm Kościoła Katolickiego wskazuje na konkretne przejawy działania Ducha Świętego w Kościele. Należą do nich przede wszystkim sakramenty, słowo Boże, łaska dana apostołom, charyzmaty, a zwłaszcza specjalne dary nazywane darami Ducha Świętego. „Życie moralne chrześcijan jest podtrzymywane przez dary Ducha Świętego. Są one trwałymi dyspozycjami, które czynią człowieka uległym, by iść za poruszeniami Ducha Świętego"11.

Tradycja Kościoła, czerpiąca ze źródeł biblijnych i patrystycznych, wymienia siedem darów Ducha Świętego (sacrum septenarium). Ta nauka doczekała się głębokiej interpretacji, zwłaszcza w teologii scholastycznej, która wnikliwie wyjaśnia znaczenie i cechy darów Ducha Świętego. Św. Paweł wielokrotnie w swoich listach (np. Gal 4, 6; Rz 8, 14-16; 1 Kor 3, 16-17) przypomina nam, że podstawowym darem Ducha Świętego (otrzymywanym już w sakramencie chrztu) jest łaska uświęcająca, wraz z którą otrzymujemy cnoty teologalne: wiarę, nadzieję i miłość oraz wszelkie cnoty wlane, które usprawniają nas do działania w Duchu Bożym. Ponadto do tego nadprzyrodzonego wyposażenia duszy, ubogaconego łaską Bożą, należą dary Ducha Świętego ${ }^{12}$. W odróżnieniu od charyzmatów, które są uzdolnieniami udzielonymi tylko pewnym osobom (dla dobra drugich), te dary Ducha Świętego zostają ofiarowane wszystkim, ponieważ mają służyć uświęceniu i udoskonaleniu osoby ludzkiej.

${ }^{8}$ Zob. Jan Paweł II, Audiencja generalna (29 XI 1989), w: Domowe rekolekcje z Janem Pawłem II, Kraków 2005, s. 39.

${ }^{9}$ Bardzo szeroko omawia to zagadnienie Y. Congar w X rozdziale (Pneumatologia Soboru Watykańskiego II) w pierwszym tomie Wierzę w Ducha Świętego, s. 227-235.

${ }^{10}$ W. Nowacki, Jak Duch Święty dziata w Kościele?, „Zeszyty Odnowy w Duchu Świętym", 24 (1998) (Kościót i Odnowa), s. 31-32.

${ }^{11}$ Katechizm Kościoła Katolickiego, Poznań 1994, nr 1830.

${ }^{12}$ Zob. Benedykt XVI, Przemówienie [...] do mieszkańców Wadowic (27 V 2006), w: Trwajcie mocni w wierze, Kraków 2006, s. 63-64. 
Gdy chodzi o nazwy tych darów, to wymienia je prorok Izajasz, opisując postać przyszłego Mesjasza: „Spocznie na nim Duch Pański, duch mądrości i rozumu, duch rady i męstwa, duch wiedzy i bojaźni Pańskiej. Upodoba sobie w bojaźni Pańskiej" (Iz 11, 2-3). Liczba tych darów zostanie później podniesiona do siedmiu (symbolika liczb!) w przekładzie Septuaginty i Wulgaty, które dodają dar pobożności, usuwają natomiast z tekstu Izajasza powtórzenie daru bojaźni Bożej ${ }^{13}$. O siedmiu darach Ducha Świętego mówi już św. Ireneusz, a po nim Orygenes. Jednak do XIII wieku na Zachodzie (można nawet dokładnie określić datę: do 1235 r.) - owe siedem darów uważano za działania łaski, czasem nawet za charyzmaty, a nie za dary różne od innych sposobów udzielania się Ducha Świętego. Niektórzy ze średniowiecznych filozofów i teologów, np. Duns Szkot, nie uznawali specyficznej odrębności darów i cnót. Również mistycy i święci w swoim doświadczeniu wewnętrznym nie rozróżniają zasadniczo łaski cnót i łaski darów. Na przykład św. Augustyn łączył dary z błogosławieństwami oraz poszczególnymi prośbami modlitwy Ojcze nasz.

Teologia darów Ducha Świętego, jako specyficznej rzeczywistości łaski, różnej od cnót i charyzmatów, zaczęła się precyzować od czasu Filipa le Chancelier (między 1235 a 1250). Przedstawimy ją, omawiając już dar rozumu $\mathrm{w}$ formie, jaką nadał jej Tomasz z Akwinu ${ }^{14}$.

Katechizm Kościoła Katolickiego wyjaśnia, że dary Ducha Świętego, będąc szczególnym uwrażliwieniem duszy ludzkiej i jej władz na działanie Boże „dopełniają i udoskonalają cnoty tych, którzy je otrzymują, czyniąc ich uległymi do ochotnego posłuszeństwa wobec natchnień Bożych"15. Można powiedzieć, że dary dostosowują się do naszych dyspozycji duchowych, udoskonalając je i otwierając w szczególny sposób na działanie samego Boga.

\section{POJĘCIE DARU ROZUMU}

Wydaje się, że spośród wszystkich darów Ducha Świętego należy postawić na pierwszym miejscu (obok daru mądrości) dar rozumu. Nie tyle ze względu na jego przedmiot i wartość spekulatywną, lecz ze względu na jego użyteczność praktyczną, życiową, tak ważną dla każdego człowieka. W naszej refleksji nad darem rozumu sięgamy najpierw do klasycznego już ujęcia, jakie dał nam Tomasz z Akwinu, który w swojej teologii darów ten dar przedstawia w sposób systematyczny w postaci aż ośmiu artykułów swojej Sumy (S. Th., II-II, q. 8) i jak mówi Congar, łączy zarówno chrześcijańskie doświadczenie,

\footnotetext{
${ }^{13}$ Zob. Jan Paweł II, Listy do kapłanów, Kraków 1999, s. 256-257.

${ }^{14}$ Zob. rozdział VII (Dary i owoce Ducha Świętego), w: Y. Congar, Wierzę w Ducha Świętego, t. 2, s. 165-175.

${ }^{15}$ KKK 1831.
} 
jak i naukę św. Pawła ${ }^{16}$. Następnie odwołamy się do ujęć współczesnych problematyki daru rozumu.

\subsection{TOMASZOWE UJĘCIE DARU ROZUMU}

Ideą przewodnią Tomaszowego przedstawienia darów Ducha Świętego jest myśl, że jedynie sam Bóg może nas poprowadzić do swojego królestwa, do swojego dziedzictwa, do swojej szczęśliwości, a więc do siebie samego. Jedynie Bóg może nam dać zdolność działania na sposób boski i czyni to m.in. poprzez dary Ducha Świętego.

W stosunku do ostatecznego celu nadprzyrodzonego, do którego rozum nas zwraca w miarę jak trochę i w sposób niedoskonały jest usprawniony przez cnoty teologiczne, nie wystarczy samo działanie rozumu, jeśli mu nie towarzyszy natchnienie i poruszenie Ducha Świętego, zgodnie ze słowami św. Pawła Apostoła (Rz 8, 14-17): „Ci, którymi rządzi Duch Boży, są Synami Bożymi [...] a jeśli dziećmi, to i dziedzicami". Podobnie śpiewamy w psalmie $(142,10)$ : „Duch Twój dobry prowadzi mnie do ziemi prawej”, gdyż nikt nie może dojść do dziedzictwa tej ziemi błogosławionej, jeśli Duch Święty go nie poruszy i nie poprowadzi. Do osiągnięcia takiego celu jest niezbędne, aby człowiek posiadał dary Ducha Świętego ${ }^{17}$.

Akwinata dodaje, że Duch Święty nie porusza ducha ludzkiego, jeśli w jakiś sposób nie jest z nim zjednoczony. Podobnie jak artysta nie porusza narzędzia, jeśli nie styka się z nim lub w jakiś inny sposób nie jednoczy się z nim. Otóż pierwsze zjednoczenie człowieka z Bogiem dokonuje się przez cnoty teologiczne: wiarę, nadzieję i miłość. Te trzy cnoty są jakby korzeniem, z którego wyrastają dary Ducha Świętego ${ }^{18}$. Warto tutaj dodać, że w terminologii Akwinaty już sam Duch Święty jest nazywany "Darem”, „Darem pierwszym”, „Darem Miłości”. Jest to nazwa osobowa, imię własne trzeciej Osoby Trójcy Świętej ${ }^{19}$.

Do tego Tomaszowego określenia Ducha Świętego jako „daru” nawiązuje Jan Paweł II:

Duch Święty jest „dobrym darem” ponad wszystkie inne [...], dobrym darem w pełnym znaczeniu tego słowa! [...] Być Miłością znaczy w Duchu Świętym to samo, co być Darem. Znakomicie tłumaczy to św. Tomasz: „Da-

\footnotetext{
${ }^{16}$ Zob. Y. Congar, Wierzę w Ducha Świętego, t. 2, s. 167.

${ }^{17}$ S. Th., I-II, q. 68 , a. 2.

${ }^{18}$ Zob. tamże, a. 4.

${ }^{19}$ Zob. S. Th., I, q. 38, a. 1-2.
} 
jemy komuś darmowo podarunek, bo mu życzymy dobra. Tak więc pierwsze i najpocześniejsze, co w darze niesiemy, to miłość, która życzy bliźniemu dobra. Jasno stąd widać, że miłość stanowi pierwszy i podstawowy dar [...]. A ponieważ Duch Święty pochodzi w postaci Miłości, pochodzi też w postaci Daru Pierwszego". Wszystkie inne dary są rozdzielane między członki ciała Chrystusowego przez Dar, którym jest Duch Święty ${ }^{20}$.

Dar rozumu jako jeden z siedmiu darów Ducha Świętego to szczególny dar Boga w człowieku. Tomasz z Akwinu nazwał rozum „ulubionym tworem Boga". Rozum jest zakotwiczony w ludzkim duchu, jest tą duchową władzą, dzięki której poznajemy, odkrywamy prawdę o człowieku, o świecie, o Bogu. Rozum jako zdolność naszego poznania tworzy pojęcia, wydaje sądy, dokonuje rozumowań. Dzięki rozumowi jest możliwa religia, nauka, sztuka, moralność, po prostu cała kultura. Dlatego jest niezwykle ważne, aby rozum prawidłowo funkcjonował, aby dobrze odkrywał prawdę, aby wydawał właściwe, obiektywne i sprawiedliwe sądy o rzeczywistości. Akwinata, rozważając, czy rozum jest darem Ducha Świętego, stwierdza: „Światło przyrodzone naszego rozumu ma moc ograniczoną, dlatego też może dojść tylko do czegoś ograniczonego. Człowiek przeto potrzebuje nadprzyrodzonego światła do dalszego wnikania i poznawania tego, czego nie zdoła poznać siłą światła przyrodzonego; właśnie owe nadprzyrodzone światło dodane człowiekowi zwie się darem rozumu"21.

Trzeba więc prosić Ducha Świętego o wspieranie naszego rozumu Jego światłem, gdyż rozum pozostawiony sam sobie może pobłądzić, może odejść od prawdy. Duch Święty w wielu tekstach biblijnych, w dokumentach Kościoła nazywany jest Duchem Prawdy. Gdy Jezus zapowiada apostołom przyjście Ducha Świętego Pocieszyciela, mówi: „Ja zaś będę prosił Ojca, a innego Pocieszyciela da wam, aby z wami był na zawsze - Ducha Prawdy" (J 14, 13.16). Takich tekstów określających Ducha Świętego jako Ducha Prawdy u św. Jana jest kilka, np.: „Gdy zaś przyjdzie On Duch Prawdy, doprowadzi was do całej prawdy" (J 16, 12).

Możemy zapytać, rozwijając myśl Akwinaty o konieczności daru rozumu do poznania prawdy, co to znaczy, że Duch Święty jest nazwany Duchem Prawdy, że doprowadza do całej prawdy? Wreszcie o jaką prawdę tu chodzi?

Z pewnością nie chodzi tu tyle o prawdę teoretyczną na temat świata czy przyrody; nie chodzi tu głównie o wiedzę przyrodzoną, dotyczącą kosmosu, której potrzebują nauki szczegółowe, przyrodnicze, ale chodzi tu przede wszystkim o prawdę dotyczącą człowieka i to w perspektywie jego zbawienia, a więc prawdę o Boga i o człowieku, jako istocie powołanej do

${ }^{20}$ Jan Paweł II, Audiencja generalna (21 XI 1990), s. 39-40.

${ }^{21}$ S. Th., II-II, q. 8, a. 1. 
życia z Bogiem w przyjaźni tu na ziemi i w wieczności. „Doprowadzenie do całej prawdy" dokonuje się w wierze i poprzez wiarę. Tego rodzaju poznanie jest właśnie dziełem Ducha Świętego, Ducha Prawdy [...]. Duch Święty pozwala człowiekowi głębiej wnikać w prawdy, w prawdy dotyczące naszego zbawienia. Po prostu oświeca ludzki umysł, uzdalniając go do poznania pełniejszej prawdy ${ }^{22}$.

Dar rozumu pomaga nam doskonalej poznać Boga już nie w stworzeniach, jak dar wiedzy, ale w prawdach, które Bóg nam objawił, które znajdują się w Piśmie Świętym i w nauce Kościoła. Słowa ludzkie i pojęcia tworzone przez rozum naturalny są nieadekwatne, zbyt ubogie, aby potrafiły zawrzeć w sobie bogactwo Bożej Prawdy. Właśnie dar Ducha Świętego, dar rozumu pozwala nam odkrywać Bożą Prawdę. Dopóki apostołowie nie otrzymali daru rozumu, nie byli w stanie należycie pojąć słów Jezusa. Dlatego Chrystus upominał ich: „To i wy jeszcze niepojętni jesteście?” (Mt 15, 16). Podobnie zwracał się św. Paweł do Efezjan: „Nie bądźcie nierozumni, ale starajcie się pojąć, jaka jest wola Boża" (Ef 5, 17).

Tomasz z Akwinu pyta też, czy dar rozumu ma tylko charakter spekulatywny, teoretyczny, dotyczy tylko naszego poznania, czy też jest czymś praktycznym, dotyczy naszego działania i odpowiada: „Dar rozumu odnosi się nie tylko do tego, co należy do wiary przede wszystkim i głównie, ale także do tego wszystkiego, co z wiarą się łączy. Postępowanie zaś dobre ma łączność z wiarą [...]; dlatego też dar rozumu rozciąga się również i na pole działania [...]o ile w działalności kierujemy się zasadami wiecznymi"23.

Trzeba zauważyć, że to właśnie Akwinata wielokrotnie podkreśla rolę darów Ducha Świętego w lepszym praktykowaniu cnót zarówno teologalnych, jak i moralnych. Dary służą po prostu doskonałemu ich praktykowaniu ${ }^{24}$.

Rozum ludzki nie wszystko poznaje i nie wszystko może zarówno wtedy, gdy osiągnie doskonałość w porządku przyrodzonym, jak i wtedy, gdy cnoty teologiczne udoskonalą go. Nie potrafi więc zwyciężyć głupoty pod każdym względem ani innych wad. Lecz Bóg, którego wiedzy i wszechmocy wszystko podlega, swoim wpływem ochroni nas od wszelkiej tępoty, głupoty i niewiedzy, od twardości serca itp. Dlatego dary Ducha Świętego, które sprawiają, że człowiek dobrze ulega natchnieniu Bożemu, stanowią lekarstwo na te wady ${ }^{25}$.

${ }^{22}$ I. Dec, Duch Święty w człowieku, „Ateneum Kapłańskie” 132 (1999), s. 210.

${ }^{23}$ S. Th., II-II, q. 8, a. 3.

${ }^{24}$ Zob. S. Th., I-II, q. 68, a. 8; II-II, q. 9, a. 1.

${ }^{25}$ S. Th., I-II, q. 68 , a. 2. 
Z kolei jako pełną aktualizację cnót w życiu człowieka, a zwłaszcza wykorzystania darów Ducha Świętego, Akwinata traktuje błogosławieństwa (wyliczone w Ewangelii św. Mateusza 5, 3-12), starając się dobrać do każdej cnoty odpowiedni dar oraz jedno z błogosławieństw. I tak działanie Ducha Świętego przez dar rozumu udoskonala wiarę, dając nam "zdrowy rozum" (sanus intellectus), pewną przenikliwość wewnętrzną. W odniesieniu do poznania Boga - kim On jest? - będzie to głębokie wyczucie transcendencji Boga, mające charakter apofatyczny. „Tym doskonalszą w tym życiu jest znajomość Boga, im jaśniej pojmujemy, że On stoi ponad wszystkim, do czego umysłem dochodzimy"26. Tomasz dodaje, że „dary bogacą nas teraz w sposób zaczątkowy, ale pełnego uwieńczenia doczekają się w przyszłości" ${ }^{27}$. W związku z tym tekstem Akwinata rozróżnia dar "rozumu zaczątkowego” (w życiu ziemskim człowieka) i dar "rozumu uwieńczonego” (w niebie).

Darowi rozumu odpowiada też, według św. Tomasza, szóste błogosławieństwo dotyczące „błogosławionych czystego serca, albowiem oni Boga oglądają"28. Mówiąc o błogosławionych czystego serca, Tomasz rozróżnia dwojaką czystość serca:

Pierwsza, poprzedzająca i przysposabiająca do oglądania Boga, to oczyszczenie serca od nieuporządkowanych uczuć; tego właśnie oczyszczenia serca dokonują cnoty i dary, przynależne władzy dążnościowej. Druga zaś czystość serca ma charakter uzupełnienia (pierwszej) do oglądania Boga; ta czystość serca polega na oczyszczeniu umysłu od złudzeń wyobraźni i od błędów; chodzi o to, aby nauki o Bogu nie przyjmować jako jakichś cielesnych wyobrażeń, czy też na sposób heretyckich ujęć; i tę czystość sprawia dar rozumu².

Trzeba również podkreślić, że Tomasz zatroszczył się nawet o to, aby każdej cnocie $\mathrm{z}$ odpowiadającym jej darem i błogosławieństwem przypisać jeden z tzw. owoców Ducha Świętego, o których mówi św. Paweł. Na przykład w Liście do Galatów wylicza on: „owocem zaś Ducha jest: miłość, radość, cierpliwość, uprzejmość, dobroć, wierność, łagodność, opanowanie" (Gal 5, 22). Na innych zaś miejscach wymienia jako „owoce” Ducha Świętego: „prawość, sprawiedliwość i prawdę" (Ef 5,9) albo: „sprawiedliwość, pobożność, wiarę, miłość, wytrwałość i łagodność” (1 Tym 6, 11) lub: „sprawiedliwość, pokój i radość w Duchu Świętym" (Rz 14, 27). Przez Akwinatę owoce te zostają określone jako "ostateczny i wspaniały skutek działania Ducha Świętego w nas" ${ }^{\prime 30}$.

${ }^{26}$ S. Th., II-II, q. 8, a. 7.

27 Tamże.

${ }^{28}$ Szeroko omawia to ewangeliczne błogosławieństwo jako korespondujące z darem rozumu - A. Drago, Dary Ducha Świętego, s. 185-194.

${ }^{29}$ Tamże.

${ }^{30}$ S. Th., II-II, q. 8, a. 8. 
Tomasz owocom Ducha Świętego poświęca nawet osobną kwestię (q. 70: O owocach Ducha Świętego), uwydatniając szczególnie rolę daru rozumu w duchowej walce człowieka z "ciałem”. Św. Paweł, do którego wprost nawiązuje Akwinata, przeciwstawia bowiem w Liście do Galatów życie według Ducha (nieustanne odczytywanie i wypełnianie woli Boga) życiu według ciała (kierowanie się tylko zmysłami). Oczywiście św. Paweł nie odrzuca ciała jako takiego, bo ono samo w sobie jest dobre, ale jego złe skłonności. Staje się to możliwe wtedy, gdy człowiek pozwala, aby Duch Święty przeniknął i uświęcił w nim wszystkie jego władze. Każdy człowiek w sposób mniej lub bardziej świadomy dokonuje wyboru pomiędzy życiem w łączności z Bogiem a życiem według zmysłów opanowanych przez grzechy. Skutki takich decyzji człowieka zostały przedstawione przez św. Pawła za pomocą dwóch katalogów: owoców Ducha i uczynków ciała. Te ostatnie zaś to: „cudzołóstwo, nieczystość, rozwiązłość, bałwochwalstwo, czary, nienawiść, kłótnie, zazdrość, gniew, chorobliwa ambicja, waśnie, rozłamy, zawiść, pijaństwo, hulanki itp." (Gal 5, 19-21).

Argumentacja Akwinaty jest następująca:

Owoce Ducha Świętego sprzeciwiają się uczynkom ciała, gdyż Duch Święty pobudza umysł ludzki do tego, co jest zgodne z rozumem, a raczej do tego, co jest powyżej rozumu; natomiast pożądanie ciała, czyli popęd zmysłowy, ciągnie człowieka do dóbr zmysłowych, które są poniżej niego. Podobnie jak ruch wzwyż i ruch w dół sprzeciwiają się sobie w przyrodzie, tak w świecie czynności ludzkich uczynki ciała sprzeciwiają się owocom Ducha $^{31}$.

Spośród wielu owoców działania w nas Ducha Świętego, darowi rozumu, podobnie jak to było w przypadku cnót teologicznych, najlepiej odpowiada wiara (nie w sensie cnoty), ale w znaczeniu „pewności wiary”, do której dochodzi człowiek poprzez ten właśnie dar Ducha Świętego ${ }^{32}$.

Podsumowując Tomaszowe ujęcie daru rozumu na tle jego teologii darów Ducha Świętego, można powiedzieć, że odbiega ono daleko od czysto racjonalnej moralności. Odbiega daleko nawet od stanowiska przypisywanego niekiedy Akwinacie, że wszystko jest regulowane przez dokładnie określoną i ponadczasową naturę rzeczy. Tomasz nie tylko przyznaje pewną "historyczność” naturze ludzkiej i „prawu naturalnemu”, ale zostawia tu szczególne miejsce dla Ducha Świętego.

Jego etyczny kosmos jest kosmosem zbawczej i uświęcającej woli Boga, opartym na zasadach, które wykraczają poza wszelką racjonalność, nawet

\footnotetext{
${ }^{31}$ S. Th., I-II, q. 70, a. 4.

${ }^{32}$ S. Th., II-II, q. 8, a. 8.
} 
nadprzyrodzoną. Ktoś Inny nas prowadzi, nie bez naszego udziału i nie przemoca, ale jednak dalej niż sięga nasz wzrok i nasze przewidywania. I to nie tylko wzrok i przewidywania naszego rozumu cielesnego, lecz także wzrok wiary i wypływające $z$ niej przewidywania ${ }^{33}$.

\subsection{WSPÓŁCZESNE UJĘCIA PROBLEMATYKI DARU ROZUMU}

Autorzy współcześnie piszący na temat darów Ducha Świętego, a zwłaszcza daru rozumu (jest on na ogół rzadko traktowany oddzielnie) niekiedy odwołują się do Tomaszowej koncepcji ${ }^{34}$. Jest ona jak gdyby fundamentem ich ujęć. Najczęściej jednak akcentują inne elementy tej problematyki. Dla przykładu przedstawimy tutaj dwa ujęcia daru rozumu: Aleksisa Riauda (wybitnego znawcy teologii Ducha Świętego i autora kilku książek o tematyce pneumatologicznej; w Polsce jest znany głównie dzięki pracy O działaniu Ducha Świętego w naszych czasach) i jezuity Mieczysława Wołoszyna (autora m.in. pracy Katechezy o siedmiu darach Ducha Świętego). Pomijamy natomiast celowo problematykę darów Ducha Świętego w piśmiennictwie rozwijającej się od lat 70. XX wieku Katolickiej Odnowy Charyzmatycznej (określanej także jako Odnowa w Duchu Świętym), gdyż jest to temat na oddzielne opracowanie.

\subsubsection{STANOWISKO A. RIAUDA}

Aleksis Riaud w swoim dziele O działaniu Ducha Świętego w naszych czasach, mówiąc o darach Ducha Świętego, na pierwszym miejscu stawia dar rozumu, akcentując jego wartość praktyczną w życiu człowieka. Przedmiotem tego daru, według tego autora, są „rzeczy i wypadki świata stworzonego"35. Do nich ludzie podchodzą bardzo różnie, reprezentując odmienne sposoby myślenia, a zwłaszcza oceny. „Dopóki dusza ocenia rzeczy doczesne na sposób ludzi światowych, nie może żyć w pełni życiem Chrystusowym [...]. Dlatego pierwszą rzeczą, jaką winno się uczynić w pogoni za doskonałością jest wyzbycie się mentalności świata, mentalności czysto ludzkiej i zastąpienia jej sposobem myślenia samego Boga [...]. Otóż na tym właśnie polega dar rozumu"36.

Mamy więc do wyboru dwa przeciwstawne sobie sposoby myślenia, wartościowania, życia. Jeden to czysto ludzki, naturalny, „światowy” i drugi -

${ }^{33}$ Y. Congar, Wierzę w Ducha Świętego, t. 2, s. 168.

${ }^{34}$ Tomaszowe ujęcie daru rozumu przedstawia np. A. Drago, Dary Ducha Świętego, s. $178-195$.

${ }^{35}$ A. Riaud, O działaniu Ducha Świętego w naszych czasach, Kalwaria Zebrzydowska 1989, s. 35.

36 Tamże. 
nadprzyrodzony, ubogacony darami Ducha Świętego (boski) ${ }^{37}$. Wybierając ten drugi, dusza ludzka, przesycona darem rozumu, rezygnuje niejako z własnego, często mylnego sądu, własnego tylko naturalnego sposobu widzenia świata, własnego myślenia. W każdej sytuacji, kierując się natomiast światłem Ducha Świętego, ma niezachwianą pewność, że się nie myli.

Dzięki darowi rozumu dusza sądzi o wszystkim jakby instynktownie w świetle wiary, tak jak sam Bóg, jak Chrystus, jak Najświętsza Maryja Panna, jak Święci. Dlatego też dusze, które oddały się Duchowi Świętemu, nie widząc się, nie porozumiewając się wcale wzajemnie, są zgodne co do sposobu oceniania wypadków tego świata, podczas gdy uczeni i teologowie mają niekiedy nawet zupełnie sprzeczne poglądy na te same sprawy ${ }^{38}$.

Człowiek napełniony Duchem Świętym i Jego darem rozumu we wszystkim, co istnieje, w każdym bycie widzi „odblask Bożych doskonałości” i czuje się wezwany do nieustannego uwielbienia Boga jako sprawcy wszelkiego dobra. A. Riaud powołuje się tutaj na przykłady, zwłaszcza św. Franciszka z Asyżu i św. Teresy od Dzieciątka Jezus. „Święty Franciszek z Asyżu odczuwał wielki szacunek i prawdziwą tkliwość dla wszystkich dzieł Bożych, ponieważ był napełniony Duchem Rozumu [...]. A bliżej naszych czasów święta Teresa od Dzieciątka Jezus, godna rywalka «powerella» z Asyżu, jest idealnym wzorem duszy całkowicie oddanej Duchowi Rozumu. Wszystko w naturze mówi jej o Bogu, wszystko sprowadza jej myśl ku wiecznej siedzibie"39. Chrześcijanin oświecony Duchem Świętym przez dar rozumu w ten sposób widzi świat, odkrywając Boga poprzez wszystkie rzeczy stworzone i codzienne wydarzenia życia.

Dar rozumu pomaga nam też właściwie oceniać zdarzenia w świecie, szczególnie te, które są dla nas przyczyną cierpień i przykrości. W Bożej perspektywie wszystko bowiem, co się dzieje, jest wypełnieniem woli Bożej i przyczynia się do zrealizowania planu, jakim jest chwała Boża przez uświęcenie osób wybranych. Riaud zauważa, że człowiek całkowicie poddany działaniu daru rozumu będzie się starał, bez względu na to, co się wydarzy, aby nie popaść w smutek i rozpacz. Wie, że Bóg go nigdy nie opuści. Człowiek kierowany Duchem Świętym ufnie wyznaje Bogu „In Te speravi, non confundar in aeternum”. Co więcej, niejako świadomie, dobrowolnie godzi się na takie bolesne doświadczenie. „Czyż nie potrzeba, aby gałązka pnia winnego była obcinana, aby móc więcej owoców wydać? Czyż nie trzeba, aby kamień, jaki ma zdobić niebieską świątynię był odpowiednio ociosany? Chętnie powtarza w doświadczeniu i upokorzeniu za psalmistą: «Bonum, quia humiliasti me» - dobrze, Panie, żeś mnie tak upokorzył"40.

${ }^{37}$ Zob. J. Dec, Duch Święty w czlowieku, s. 215.

${ }^{38}$ A. Riaud, O dziataniu Ducha Świętego w naszych czasach, s. 35.

${ }^{39}$ Tamże, s. 36.

${ }^{40}$ Tamże, s. 37-38. 
Można nawet powiedzieć, że człowiek korzystający z boskiego daru rozumu cieszy się z tego, że jest upokorzony, poddany bolesnemu doświadczeniu, bo wie, że jest to najkrótsza i najpewniejsza droga do osiągnięcia doskonałego wyrzeczenia się i doskonałej miłości. A. Riaud dodaje, że wszyscy święci dzięki darowi rozumu podobnie oceniali cierpienie, a zwłaszcza upokorzenia. „Dziękuję Ci, o Boże - mówiła św. Teresa od Dzieciątka Jezus - za wszystkie łaski, jakich udzieliłeś mi, a szczególnie za to, żeś przeprowadził mnie przez tygiel cierpienia"41.

Ukazując działanie daru rozumu w człowieku, Riaud podkreśla za św. Pawłem, że w duszy wiernej Bogu Duch Święty dokonuje prawdziwych cudów - mianowicie sprawia, że wszystko w naturze staje się dla niej okazją do uwielbienia Boga i do składania Mu ciągłego dziękczynienia. Natomiast dla duszy zniewolonej grzechem przeciwnie, wszystko staje się okazją do pokus i upadków. Przypomina o tym św. Paweł w Liście do Tytusa: „Dla czystych wszystko jest czyste, dla skalanych zaś, niewiernych nie ma nic czystego, bo skalany jest ich umysł i sumienie" (Tyt 1,15$)$. Stąd też człowiek, który we wszystkim pragnie kierować się darem rozumu, powinien przede wszystkim starać się o czystość duszy i „wielką delikatność sumienia, unikając jak zarazy wszelkiej dobrowolnej winy, nawet w rzeczach mało znaczących"42.

A. Riaud kończy bardzo ważnym stwierdzeniem, że nie wystarczy zachować Ducha Świętego w duszy, unikając grzechu śmiertelnego, ale trzeba ponadto troszczyć się o to, aby nie utrudniać Jego działania, usiłując wykluczyć wszelkie dobrowolne niedoskonałości. Każda bowiem, nawet najmniejsza niewierność, jeśli tylko występuje często i całkowicie dobrowolnie, pociąga za sobą jako konieczny skutek zatwardziałość serca i zaćmienie umysłu, a tym samym wypacza nasze myślenie i wartościowanie, stanowiąc przeszkodę dla działania boskiego daru rozumu w naszej duszy ${ }^{43}$.

\subsubsection{UJĘCIE M. WOŁOSZYNA}

Pod pewnym względem kontynuacją refleksji A. Riauda nad darem rozumu w życiu człowieka są rozważania Mieczysława Wołoszyna z jego pracy Katechezy o siedmiu darach Ducha Świętego. Na wstępie stwierdza on, że dary Ducha Świętego mają się przeciwstawić siedmiu darom innego, złego ducha, czyli siedmiu grzechom głównym. „Duch Święty w miejsce siedmiu grzechów głównych chce w nas zapalić siedem świateł - siedem znaków mocy. I chodzi o to, żebyśmy się nauczyli świadomie współpracować z darami Ducha Święte-

\footnotetext{
${ }^{41}$ Tamże, s. 38 .

42 Tamże, s. 39.

${ }^{43}$ Zob. tamże.
} 
go" $^{\prime \prime 4}$. Dary te otrzymujemy zwłaszcza w sakramencie bierzmowania. Niestety - zauważa M. Wołoszyn - z przeżywaniem tego sakramentu jest "gorzej niż źle". Akt bierzmowania nie przekłada się bowiem na nasze życie. Nie wykorzystujemy w sposób właściwy darów Ducha Świętego.

Gdy chodzi o dar rozumu (autor najczęściej zestawia go z darem mądrości), to na ogół mamy błędne skojarzenia, przede wszystkim co do funkcji tego daru. Wydaje się nam, że przez dar rozumu osiągamy zwiększone naturalne możliwości poznawcze, lepsze zdolności działania naszego intelektu w różnych dziedzinach. W tym znaczeniu młodzi ludzie, np. przed egzaminami maturalnymi, proszą Boga o dar rozumu. Jest to zupełne nieporozumienie. Zdaniem Wołoszyna, „chodzi o sprawę trudną, bardzo trudną. Mianowicie Dar Rozumu ma prześwietlić nasze emocje, uporządkować nasze emocje. Nie tylko nienawiść, nie tylko egoizm, ale przede wszystkim ma się uporać z pychą" ${ }^{45}$. To właśnie pycha (jej działanie widzimy na przykład w duszy Judasza) stoi na przeszkodzie daru rozumu. To ona sprawia, że nie dostrzegamy braku rozumu w naszym działaniu. Co więcej, uważamy, że mamy go dostatecznie dużo, nawet w nadmiarze. Wołoszyn bardzo krytycznie zauważa, że

$\mathrm{z}$ tym rozumem $\mathrm{w}$ każdym $\mathrm{z}$ nas jest tak, że wszystkiego $\mathrm{w}$ imieniny można bliźniemu życzyć, ale nie wolno mu życzyć nigdy rozumu, bo się obrazi. Brakuje nam wielu rzeczy, zdrowia, inteligencji, pamięci, tylko z rozumu każdy jest zadowolony [...]. Rozumu mamy tyle, że każdemu możemy nim służyć, nawet Boga chętnie byśmy pouczyli. To oznacza, że pokory umysłu i serca - Daru Rozumu - nie ma w nas zbyt wiele ${ }^{46}$.

Przez dar rozumu Duch Święty pragnie udoskonalić funkcjonowanie naszego rozumu „omotanego złymi przywiązaniami, emocjami”. Żyjemy w świecie otaczającego nas zła. To zło występuje także w nas samych. "Z wnętrza bowiem, z serca ludzkiego pochodzą złe myśli, nierząd, kradzieże, zabójstwa, cudzołóstwa, chciwość, przewrotność, podstęp, wyuzdanie, zazdrość, obelgi, pycha, głupota” (Mk 7, 21-22). Żeby nie zatonąć w tym „morzu” nieprawości, Duch Święty chce nasz ludzki rozum ubogacić potężnym darem, jakim jest dar rozumu. W języku biblijnym termin „morze” jest symbolem złych sił, miejscem działania szatana, ducha zamętu, chaosu, śmierci. W jednej ze swoich przypowieści Chrystus właśnie do „morza” porównał świat, w którym musimy tak żyć, aby się zbawić. Duch Święty ten wspomagający nas dar rozumu ofiarowuje nam w Piśmie Świętym. A. Wołoszyn księgi Biblii porównuje do rybackich sieci, które mają nas wyłowić ze zła i chaosu tego świata. „Bez sieci nie ma

\footnotetext{
${ }^{44}$ M. Wołoszyn, Katechezy o siedmiu darach Ducha Świętego, wyd. 2, b.m. 2003, s. 8.

${ }^{45}$ Tamże, s. 26.

${ }^{46}$ Tamże.
} 
połowu ryb. Czyli bez Pisma św. nie można uratować świata. Jeżeli kiepskie są sieci, to i połów będzie kiepski. Byle jaka znajomość Pisma św. przez kapłanów (i wiernych) nic dobrego nie wróży"47.

Oczywiście nie chodzi tutaj o teoretyczną znajomość Pisma Świętego, ale o zastosowanie praktyczne mądrości Biblii, jej wskazań, jak postępować, jak po prostu żyć ${ }^{48}$. W tym szczególnie pomoże nam dar rozumu. Ludzki rozum, wzbogacony darem rozumu udzielonym przez Ducha Świętego, można porównać do słońca w naszym świecie. Jest ono konieczne do życia. Bez jego światła i ciepła nie ma życia. Wszystko ginie w ciemnościach. Jeśli ludzkiego rozumu nie oświeci boski dar rozumu, wówczas człowiek staje się , jako bóg" - pycha i egoizm jego serca wszystko absolutyzuje, zamyka, pogrąża w ciemnościach i chaosie zła. On sam dostaje się w ręce szatana. Wołoszyn podkreśla, że jest rzeczą niesłychanie ważną odkrycie i zdemaskowanie taktyki złego ducha, którą przebiegle stosuje, aby człowieka pogrążyć w złu. „Otóż taktyka szatana polega na tym, że działa bardzo cierpliwie, długofalowo, małymi dawkami wsącza nam zło. Takimi dawkami, że one nie powodują szoku naszego sumienia" ${ }^{\prime 4}$. Pod wpływem takiej strategii złego ducha człowiek stopniowo, systematycznie przyzwyczaja się do zła. Dlatego metodą działania Boga na zło jest wstrząs. Dokonuje tego boski dar rozumu oświecający człowieka. On pozwala nam zrozumieć naszą sytuację, nasz grzech. Początkiem działania $\mathrm{w}$ nas daru rozumu będzie więc uświadomienie sobie zła, odwrócenie się od niego i skierowanie ku dobru.

Mieczysław Wołoszyn, podsumowując swoje refleksje, posługuje się następującym obrazem:

Wyobraźmy sobie człowieka w łodzi na ogromnych wodach jeziora czy morza. Jeśli nie ma ani wioseł, ani żagli ze sterem - marny jego los. Wiosła można porównać do cnót człowieka. Wiosła wymagają trudu, ale jest nadzieja, ze człowiek nie zginie. Natomiast dary Ducha Świetego - to tak jakby ów człowiek otrzymał żagle ze sterem. Teraz ważny jest wiatr - natchnienie Ducha Świętego ${ }^{50}$.

\section{ZAKOŃCZENIE}

Współczesny świat, jak nigdy przedtem, potrzebuje nowego cudu zesłania Ducha Świętego. Potrzebuje ciągle powtarzającego się cudu "wylania" Ducha Świętego z jego siedmiorakimi darami. Nic bowiem nie jest tak ko-

\footnotetext{
${ }^{47}$ Tamże, s. 28.

${ }^{48}$ Zob. Z. Radziwołek, Dary Ducha Świętego w życiu chrześcijanina, s. 306-307.

${ }^{49}$ M. Wołoszyn, Katechezy o siedmiu darach Ducha Świętego, s. 30.

${ }^{50}$ Tamże, s. 78-79.
} 
nieczne dzisiejszemu „zeświecczonemu” światu jak duchowa odnowa, którą sprawia Duch Święty. Wydaje się, że światu, naszej ojczyźnie, a zwłaszcza nam wierzącym Polakom potrzeba szczególnego „bierzmowania dziejów”, tak jak to już wielokrotnie dokonywało się w historii. Pamiętamy chyba wszyscy dobrze ten moment zwrotny w naszej najnowszej historii, gdy Jan Paweł II po raz pierwszy stanął na ojczystej ziemi. Wołał wtedy (2 VI 1979) na placu Zwycięstwa w Warszawie: „Niech zstąpi Duch Twój i odnowi oblicze ziemi, tej ziemi”. Tamto historyczne już wołanie Papieża, płynące z głębokiej wiary, że Bóg mocą Ducha Świętego wszystko odnawia i uświęca, zostało wysłuchane. Możemy to ocenić tym bardziej teraz, po tamtych latach.

Dziś znowu potrzeba nam tej mocy Ducha Świętego, korzystania z Jego darów, a zwłaszcza daru rozumu. Dlatego musimy nieustannie przyzywać Ducha Świętego i „szczerym sercem” otwierać się na Jego działanie. Niech Duch Święty Pocieszyciel porusza skutecznie nasze serca i zwraca je ku Bogu, niech otwiera oczy naszego rozumu i prowadzi do poznania prawdy. Oby mogły spełnić się słowa Chrystusa: „Gdy zaś przyjdzie On, Duch Prawdy, doprowadzi was do całej prawdy" (J 16, 13).

\section{THE GIFT OF UNDERSTANDING AND ITS GIVER IN CHRISTIAN LIFE}

\section{SUMMARY}

Every Christian is called to make use of the power of the Holy Spirit in his life. In the first part of the present article the reality of the Holy Spirit in general and as a giver of different gifts in the community of the Church is discussed. Then, in more specific and broad way, the working of the gift of understanding as an extraordinary gift of God's grace is shown.

Our reflection upon the Divine gift of understanding is based in this part of the article mainly on classical explanations given by St Thomas Aquinas in his theology of the gifts of the Holy Spirit. In the last part of the article two contemporary conceptions of the problem discussed above are shown: gift understanding according to Alexis Riaud (outstanding expert in theology of the Holy Spirit and author of many works on pneumatology) and according to Mieczyslaw Woloszyn (author of the book: "Catechesis on the seven gifts of the Holy Spirit"). 